\title{
Flexural behaviour of cold formed steel beams with Diagonal stiffener
}

\author{
Pooja S.Ajay $^{\# 1}$, Asst. Prof. J Samuel ${ }^{* 2}$, Dr. P.S Joanna ${ }^{\# 3}$, Prof. Eapen Sakaria ${ }^{* 4}$ \\ \# P.G Student \& Department of Civil Engineering \& Saintgits College of Engineering, Kottayam, Kerala, India \\ * PhD Scholar \& Department of Civil Engineering \& Hindustan University, Chennai, India \\ \# Professor \& Department of Civil Engineering, Hindustan University, Chennai, India \\ * Prof.\& Head \& Department of Civil Engineering \& SaintGits College of Engineering, Kottayam, Kerala, India
}

\begin{abstract}
The adaptability of the different shapes and sizes of section that are available leads to the potential use of Cold Formed Steel as a complete building material. To improve the elastic buckling stress of the whole thin-walled I section including flanges and lips in pure shear, intermediate stiffeners are added. In this paper, the results of the experiments conducted on coldformed steel beam encased with diagonal stiffened webs with a view to study their flexural strength are presented.

A total of 6 specimens were tested. 2 specimens each of coldformed steel I section, cold-formed steel I section with diagonal stiffeners and cold-formed steel I section with diagonal stiffeners in filled with concrete was used. All the specimens were tested for flexural strength under two point loading by using reaction type vertical loading frame. Ultimate load carrying capacity and ultimate deflection of each type of beam is calculated and compared. From the experimental investigations carried out to study the flexural behaviour of encased cold-formed steel beams with and without stiffeners, it was found that Cold-formed steel section with stiffeners in filled with concrete has resulted in increased resistance to lateral-torsion buckling.
\end{abstract}

Keywords - Cold-formed steel beam, diagonal stiffener, in filled beam, flexural behaviour

\section{INTRODUCTION}

The use of cold-formed steel structures is increasing rapidly around the world. Cold formed steel elements are either stiffened or unstiffened. An element which is supported by webs along both its longitudinal edges is called a stiffened element. An unstiffened element is one, which is supported along one longitudinal edge only with the other parallel edge being free to displace. An intermittently stiffened element is made of a very wide thin element which has been divided into two or more narrow sub elements by the introduction of intermediate stiffeners, formed during rolling.

The adaptability of the different shapes and sizes of section that are available leads to the potential use of CFS as a complete building material for primary beams, floor units, roof trusses, stud walls and portions. In all cases the cold formed steel sections are made from galvanised strip steel with a range of thickness of typically between $0.9 \mathrm{~mm}$ to $3.2 \mathrm{~mm}$. Thin walled steel sections tend to be more sensitive to local buckling effects than typically hot rolled sections. To improve the elastic buckling stress of the whole thin-walled I section including flanges and lips in pure shear, intermediate stiffeners are added. The similar specimens are encased with concrete and its flexural capacity was tested. In the following section, the behaviour of a hollow I section beam is compared with the behaviour of steel encased with_concrete beams through experimental tests and theoretical analysis.

A total of six cold-formed steel beams with plain web, stiffened web and encased stiffened web were tested. Out of the six specimens, two controlled specimens were tested with plain web and the other four specimens were tested with stiffened web and encased stiffened web. The specimens were tested under two point loading for its pure flexural behaviour.

\section{EXPERIMENTAL INVESTIGATION}

\section{A. Test Specimen Details}

The test specimens consist of cold-formed steel beams with plain web, stiffened web and encased stiffened web. The span of the beam was $2000 \mathrm{~mm}$ and the cross sections of the I-beams are $150 \mathrm{~mm} \times 100 \mathrm{~mm} \mathrm{x} 2 \mathrm{~mm}$. The yield strength of steel used is $380 \mathrm{~N} / \mathrm{mm}^{2}$ and the web is encased with M 30 grade concrete. The cold-formed steel beam is built up by welding the flanges and the web using intermittent welds of $4 \mathrm{~mm}$ thickness. A pair of stiffeners was provided at both the load points to minimize local effect due to concentrated loads. Figure 1 shows the fabricated specimens and Table- 1 shows the details of the beams tested. A five lettered designation is given to the specimens. First 4 letters represents the nature of web whether it is plain or braced or encased with concrete and the $5^{\text {th }}$ letter indicates the specimen number. 


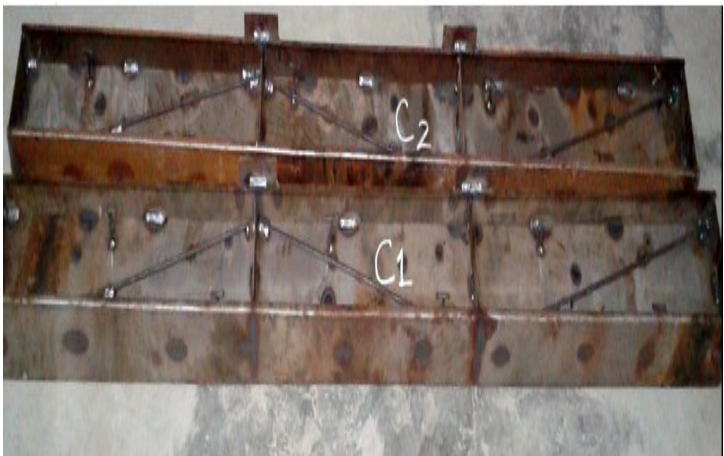

Fig 1: Cold Formed Steel Beam with Diagonally Stiffened Web

TABLE 1

DETAILS OF THE SPECIMENS TESTED

\begin{tabular}{|c|l|}
\hline SL.No: & Beam Number \\
\hline 1 & NPWB - I \\
\hline 2 & NPWB - II \\
\hline 3 & NBWB - I \\
\hline 4 & NBWB -II \\
\hline 5 & EBWB - I \\
\hline 6 & EBWB - II \\
\hline
\end{tabular}

\section{B. Test set-up}

The testing was carried out in a loading frame of $400 \mathrm{kN}$ capacity. All the specimens were tested for flexural strength under two point loading. The specimens were arranged with simply supported conditions having an effective span of $1.8 \mathrm{~m}$. Loads were applied at one-third distance from the supports at a uniform rate till the ultimate failure of the specimens occurred. Beam deflections were measured at several locations using Linear Variable Displacement Transducers (LVDTs) as shown in the Figure 2. Strain gauges and LVDTs were connected to a data logger from which the readings were captured by a computer at every load intervals until failure of the beam occurred. The experimental set-up for the test specimens are shown in Figure 3.

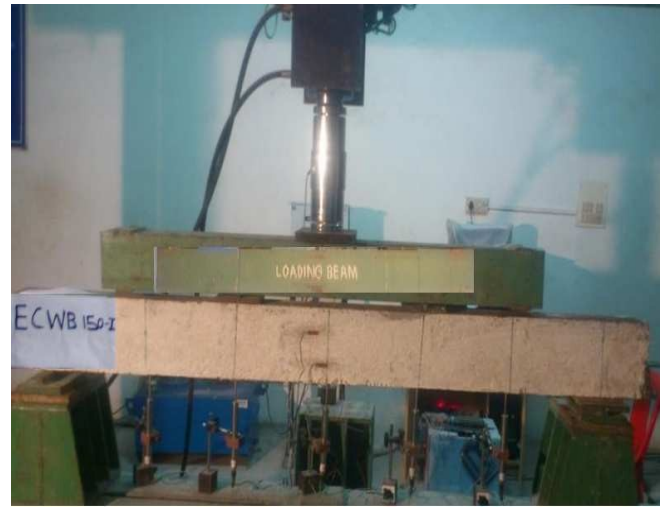

Fig 2: Experimental set-up for the test specimens

\section{RESULTS AND DISCUSSIONS}

All the specimen were tested for flexural strength under two point loading by using reaction type movable loading frames .Deflection and strain readings are observed from DATA logger.

The following observations were made during the progress of the tests. The observations are summarized in the following :

TABLE 2

ULTIMATE LOADS AND DEFLECTION OF THE SPECIMENS

\begin{tabular}{|l|l|l|}
\hline Specimens & $\begin{array}{l}\text { Ultimate } \\
\text { load in KN }\end{array}$ & $\begin{array}{l}\text { Max. } \\
\text { Deflection at } \\
\text { Mid -Span in } \\
\mathrm{mm}\end{array}$ \\
\hline NPWB -I & 17 & 6.5 \\
\hline NPWB -II & 15.2 & 13.9 \\
\hline NBWB-I & 30.8 & 9.5 \\
\hline NBWB-II & 30 & 13.8 \\
\hline EBWB -I & 72.4 & 19.7 \\
\hline EBWB -II & 92.6 & 24.9 \\
\hline
\end{tabular}

\section{A. LOAD versus DEFLECTION}

The linear Variable Displacement Transducers were used to measure deflection for the specimens at mid-span and one third of the span length .The obtained deflections were plotted against their corresponding load values obtained from the experimental results. 


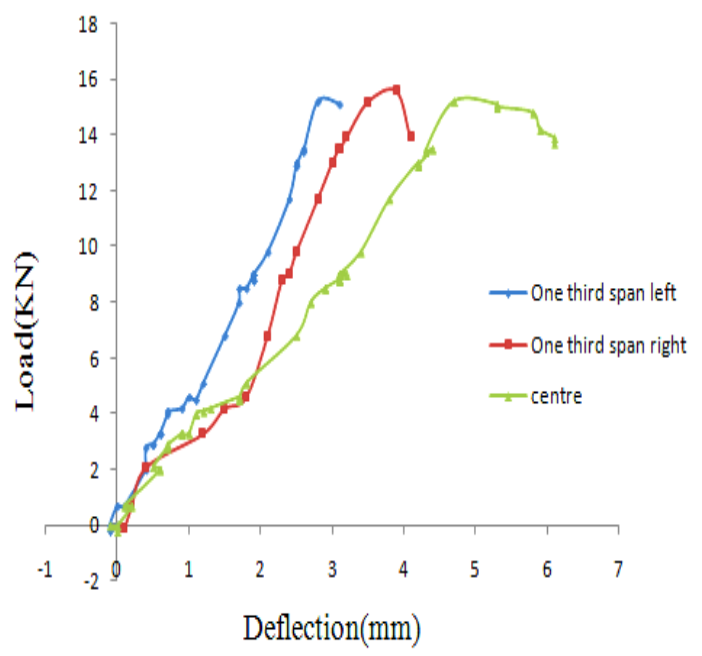

Fig 3 Load v/s deflection graph for normal beam

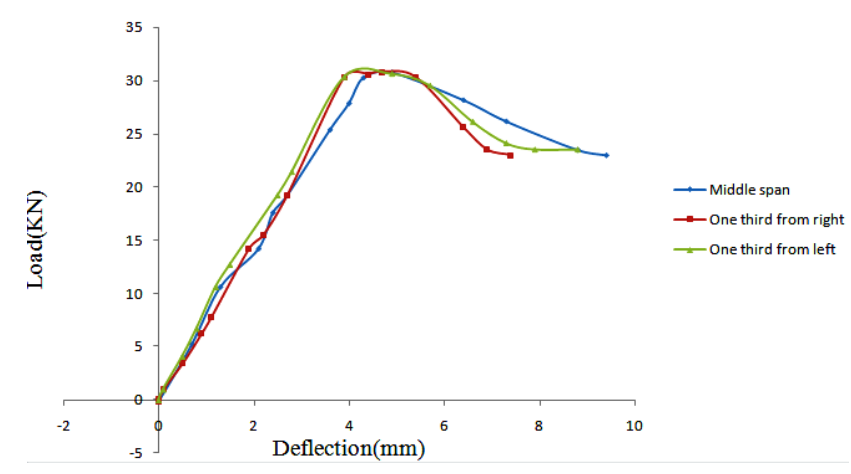

Fig 4 Load v/s deflection graph for diagonally stiffened beam

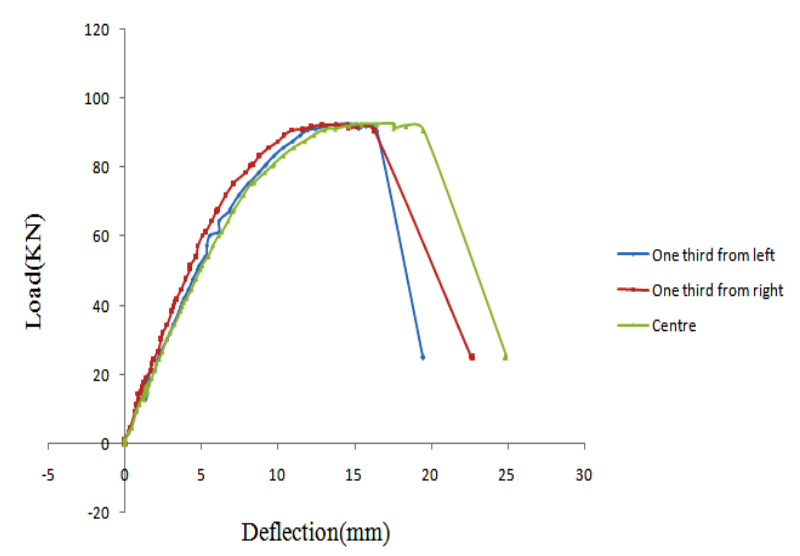

Fig 5 Load v/s deflection graph for encased diagonally stiffened beam

\section{B. LOAD versus STRAIN}

The linear Variable Displacement Transducers were used to measure the strain developed for the specimens at midspan and one third of the span length .The obtained strain values were plotted against their corresponding load values obtained from the experimental results.

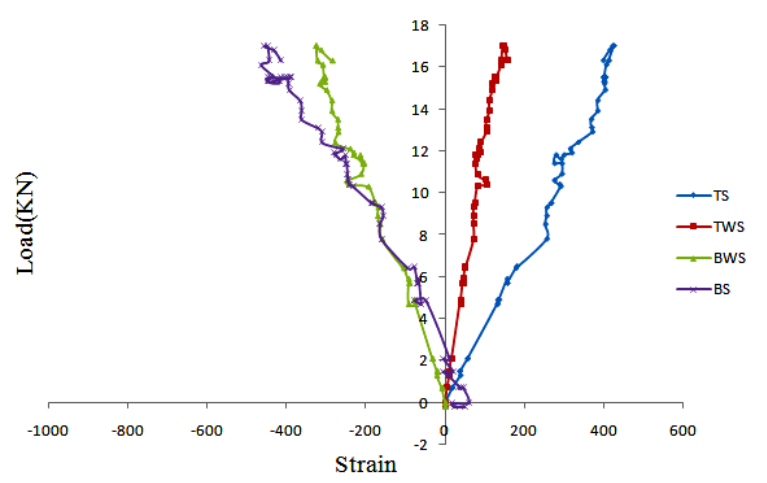

Fig 6 Load v/s strain graph for normal beam

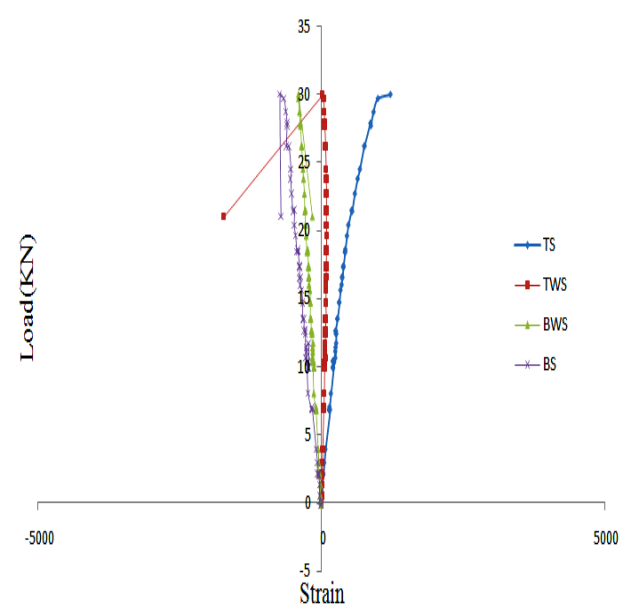

Fig 7 Load v/s strain graph for diagonally stiffened beam

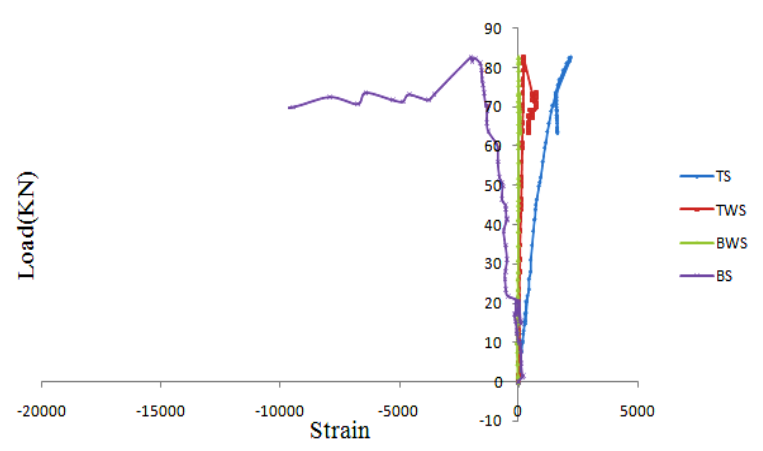

Fig 8 Load v/s strain graph for encased diagonally stiffened beam 


\section{International Journal of Engineering Trends and Technology (IJETT) - Volume17 Number 8-Nov2014}

\section{Comparison Of Ultimate Loads}

Comparison of the ultimate loads of normal I section, diagonally stiffened beams and encased diagonally stiffened beams were carried out. The ultimate load of normal I section was $17 \mathrm{KN}$ and the ultimate deflection was $6.5 \mathrm{~mm}$. The ultimate load of diagonally stiffened beam was $30.8 \mathrm{KN}$ and ultimate deflection was $9.5 \mathrm{~mm}$. The ultimate load of encased diagonally stiffened beam was $92.6 \mathrm{KN}$ and ultimate deflection of $24.9 \mathrm{~mm}$.

Fig: 3.7 show the comparison of ultimate load carrying capacity of the three different types of beams.

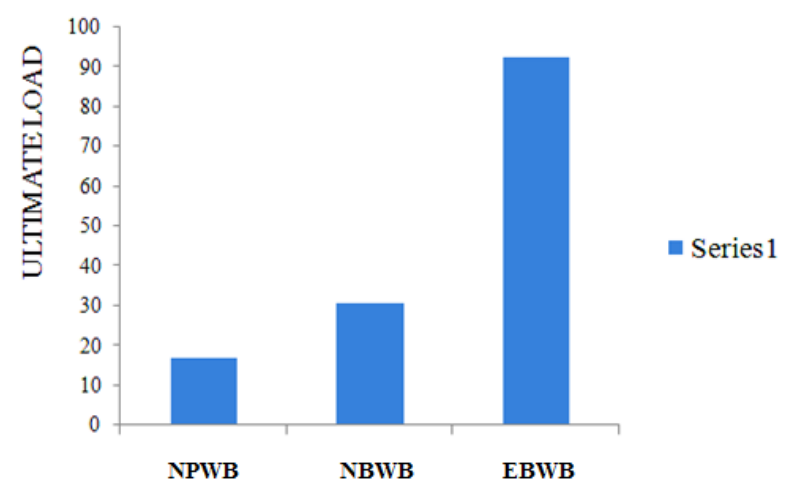

Fig 9 Comparison of ultimate load carrying capacity

\section{Comparison Of Ultimate Deflection}

Comparison of the ultimate deflection of normal beam, diagonally stiffened beams, diagonally stiffened beam encased with concrete were carried out. At $17 \mathrm{KN}$ the deflection for normal I section is $6.5 \mathrm{~mm}$ and for the same load the beam with diagonal stiffener has a deflection of $2 \mathrm{~mm}$. Similarly in the case of beam with diagonal stiffener encased with concrete, the deflection is $0.5 \mathrm{~mm}$

Fig: 3.8 show the comparison of ultimate deflection of the three different types of beams

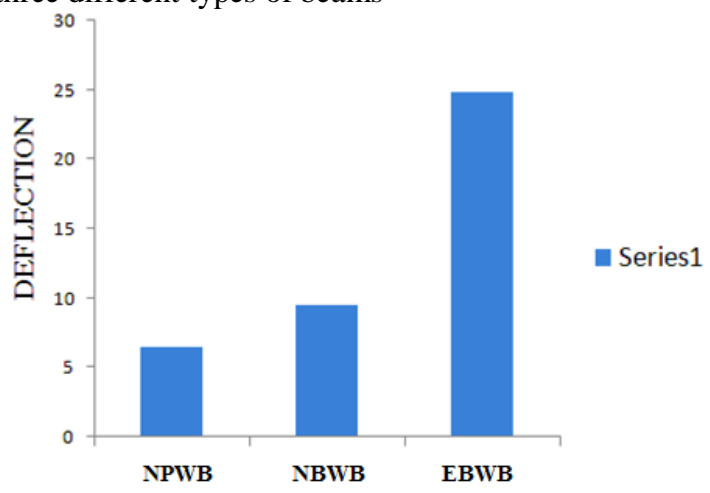

Fig 10 Comparison of ultimate deflection

\section{E. Modes Of Failure}

From the results of experimental analysis the failure modes of the specimens are discussed.

The failure was typically in the form of flexural cracks originating from the bottom of the specimen and extending towards the top of the specimen in the case of encased specimens. The majority of cracks were formed between the zone of two point loading and also some cracking was also observed near the supports end. The load carrying capacity of encased web beam was significantly higher than that of normal web beam.

Though failure because of loss of bond between steel web and concrete was expected such a failure did not occur. The bonding nature of concrete and interlocking effect provided by the shear studs and flange lips was found to be enough to ensure bonding for beam tasted depth. The buckling of flange in outward direction was observed due to the lack of welding in that region.

The following pictures show the failure pattern observed in the specimens tested.

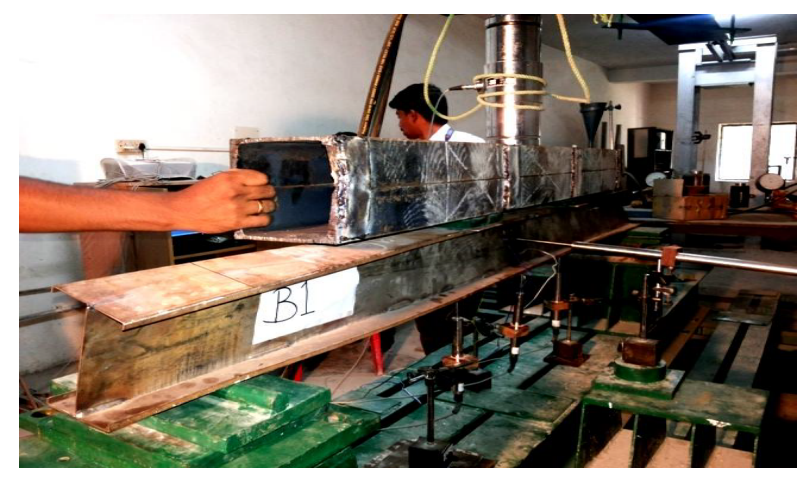

Fig 11 Failure of normal beam NPWB

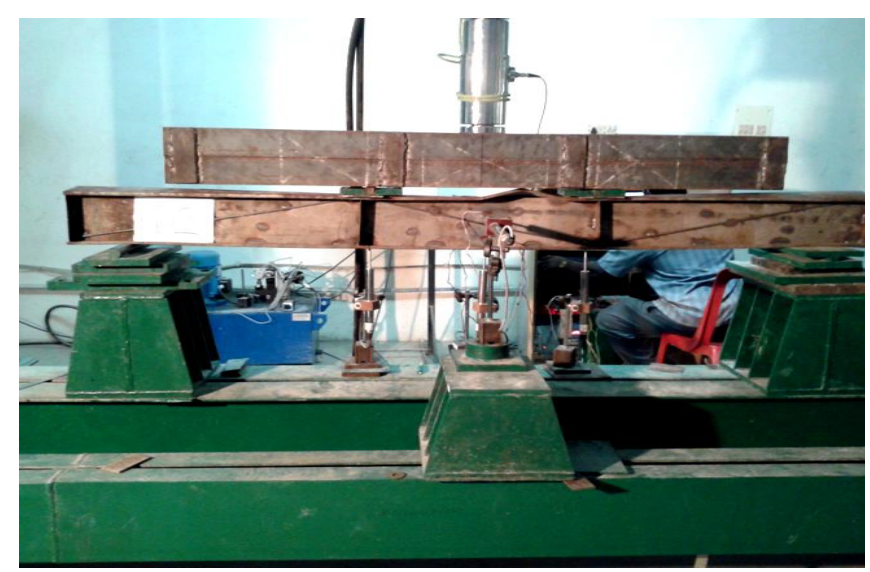

Fig 12 Failure of diagonally stiffened beam NBWB-I 


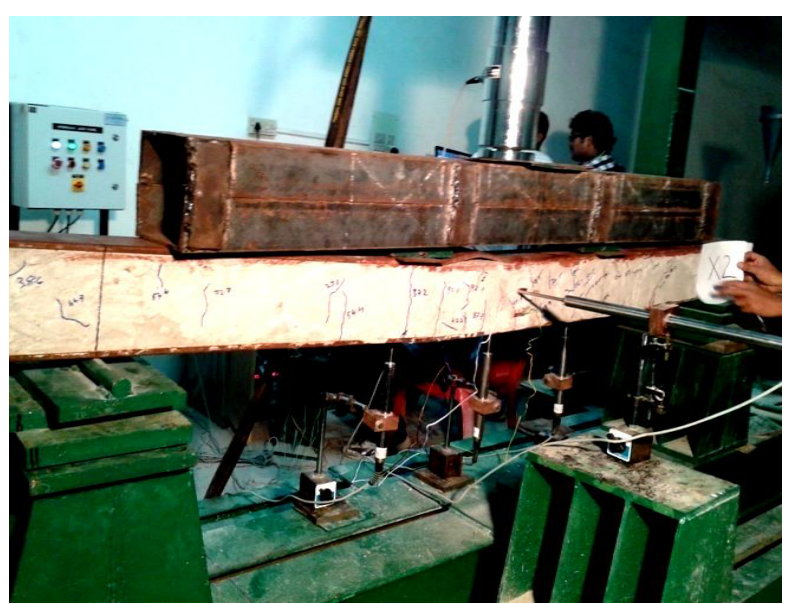

Fig 13 Failure of diagonally stiffened beam encased with concrete

\section{CONCLUSIONS}

The main objective of the project was successfully accomplished. From the experimental investigations carried out to study the flexural behaviour of encased cold-formed web beams, the following conclusions are drawn.

$>$ Cold-formed section with concrete has resulted in increased resistance to lateral-torsional buckling.

$>$ The ultimate load of normal beam was $17 \mathrm{KN}$ and the ultimate deflection was $6.5 \mathrm{~mm}$. The ultimate load of beam with stiffener in the web was $30.8 \mathrm{KN}$ and ultimate deflection $19.7 \mathrm{~mm}$. The ultimate load of beam with encased web was $92.6 \mathrm{KN}$ and ultimate deflection of $24.9 \mathrm{~mm}$.

$>$ At $17 \mathrm{KN}$ the deflection for normal beam is $6.5 \mathrm{~mm}$ and for the same load the beam with bracing in the web has a deflection of $2 \mathrm{~mm}$. Similarly in the case of beam with encased web the deflection is 0.75 $\mathrm{mm}$

$>$ The ultimate load carrying capacity of cold- formed light gauge steel I section with stiffener was $40-45 \%$ higher than that of cold- formed light gauge steel I section.

$>$ The ultimate load carrying capacity of cold- formed light gauge steel I section with stiffener filled with concrete was $80-85 \%$ higher than that of coldformed light gauge steel I section.

$>$ The ultimate deflection of cold- formed light gauge steel I section with stiffeners was $65-70 \%$ lesser than that of cold- formed light gauge steel I section.
$>$ The ultimate deflection of cold- formed light gauge steel I section with stiffener filled with concrete was $85-90 \%$ lesser than that of cold- formed light gauge steel I section.

\section{REFERENCES}

[1] Rajeshkumar.B, Anil Kumar Patidar and Helen Santhi. M, "Fe Analysis Of Concrete Filled Cold Formed Steel Sections Using Ansys" IJACE Vol.3 No.1 JanuaryJune 2013, pp. 11-18

@ Research Sciences Press, (India)

[2] Lincy P Abraham, Divahar R, Dr. P.S.Joanna, T.M.Matthai , "Behaviour of Encased Cold-Formed Trapezoidally Corrugated Web Beam" International Journal Of Engineering Sciences \& Research Technology, October 2013

[3] Khandaker M. Anwar Hossain, "Experimental \& theoretical behavior of thin walled composite filled beams" ,Electronic Journal of Structural Engineering, 3 (2003)

[4] Sudha.K , Sukumar. S , "Behaviour of Cold-Formed Steel Built-up I Section Under Bending” International Journal of Engineering and Technology (IJET)

[5] Papia Sultana , "Predictions of Flexural Behaviour of Built- Up Cold-Formed Steel Sections”, A thesis presented to the University of Waterloo

[6] Jianguo Nie, Yan Xiao, Ying Tan A and Hogguan Wang (2004), “ Experimental studies on behaviour of composite steel high strength concrete beams", ACI Structural Journal ,Vol 129, No: 4, pp. 245-251

[7] Kottiswaran N, Sundararajan. R, "Behaviour Of Thin Walled Cold Formed Steel Concrete Composite Beams," Proceedings Of National Seminar- REDECON 2005, pp. 373-381

[8] Thenmozhi R, Sundararajan. R, Kiruthika R, "Flexural Behaviour Of Thin- Walled Steel- Stiffened Concrete Composite Beams", Steel In Construction, Technical Journal Of Institute Of Steel Development \& Growth, No: 2, 6 (2005) pp 43-54

[9] Arivalagan. S, Kandasamy. S "Finite Element Analysis On The Flexural Behaviour Of Concrete Filled Steel Tube Beams", Journal Of Theretical And Applied Mechanics, Warsaw 2010, 48, 2, pp 505-516

[10] Luis Laim, Joao Paulo C Rodrigues, Luis S Silva, "Flexural Behaviour Of Cold Formed Steel Beams", DFE 2013- International Conference on Design, Fabrication and Economy of Metal Structures, (ISBN: 978-3-642-3669019), Hungary

[11] Jia-Hui Zhang, Ben Young, "Compression test of cold-formed steel I-shaped open sections with edge and web stiffeners", Thin-Walled Structures 52 (2012) 1-11

[12] IS 10262: 2009, Concrete Mix ProportioningGuidelines- Bureau of Indian Standards 